\title{
Water Quantity and Quality under Future Climate and Societal Scenarios: A Basin-Wide Approach Applied to the Sorraia River, Portugal
}

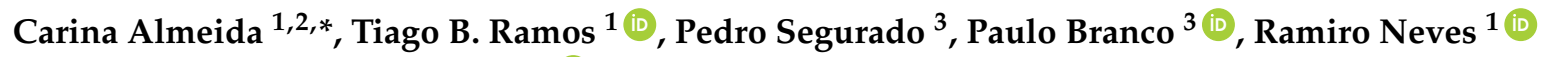 \\ and Rodrigo Proença de Oliveira 4 (iD \\ 1 Centro de Ciência e Tecnologia do Ambiente e do Mar, Instituto Superior Técnico, Universidade de Lisboa, \\ Av. Rovisco Pais, 1, 1049-001 Lisboa, Portugal; tiagobramos@tecnico.ulisboa.pt (T.B.R.); \\ ramiro.neves@tecnico.ulisboa.pt (R.N.) \\ 2 AQUALOGUS, Rua do Mar da China N. 1 Escritório 2.4, Parque das Nações, 1990-137 Lisboa, Portugal \\ 3 Centro de Estudos Florestais, Instituto Superior de Agronomia, Universidade de Lisboa, 1349-017 Lisboa, \\ Portugal; psegurado@isa.ulisboa.pt (P.S.); pjbranco@isa.ulisboa.pt (P.B.) \\ 4 Civil Engineering Research and Innovation for Sustainability, Instituto Superior Técnico, 1049-001 Lisboa, \\ Portugal; rodrigopoliveira@tecnico.ulisboa.pt \\ * Correspondence: carina.almeida@tecnico.ulisboa.pt; Tel.: +35-121-841-9428
}

Received: 2 August 2018; Accepted: 30 August 2018; Published: 4 September 2018

\begin{abstract}
Water resources are impacted by several stressors like over-population and over consumption that compromises their availability. These stressors are expected to progressively intensify due to climate change in most regions of the world, with direct impact on watersheds and river systems. This study investigates the effect of different watershed pressure scenarios due to climate change in the hydrological regime of the Sorraia River basin, Portugal. This catchment includes one of the largest irrigated areas in the country, thus being strongly influenced by anthropogenic activities, associated to hydrological (irrigation, flow regulation, damming) and nutrient stressors. The Soil Water Assessment Tool has been used to simulate water flow and nutrient dynamics in the watershed while considering inputs from two climate models and three societal scenarios. Results have shown that the predicted rainfall reductions will have a significant impact on river flow and nutrient concentrations when compared to baseline conditions. River flow will expectably decrease by $75 \%$, while nitrogen and phosphorus concentrations in river water will expectably increase by $500 \%$ and $200 \%$, respectively. These differences are more evident for storylines that consider increasing pressures such as population growth and agricultural expansion marked with unsustainable practices and increased reliance on technology. The results of this study indicate a possible future outcome and provide effective guidelines for the formulation of water management policies to counter the impacts of climate change and corresponding environmental pressures in the Sorraia River basin.
\end{abstract}

Keywords: hydrological modelling; climate change; basin management scenarios; Sorraia River Basin

\section{Introduction}

Agriculture is one of the main factors responsible for variation in the landscape of a region [1]. Unsustainable agricultural practices and excessive urban expansion have drastically affected the hydro morphological characteristics of river systems in the wake of climate change. The ever-increasing world population and globalisation of food products is one of the major reasons for the expansion of agroecosystems. High demands from the global food market have turned small and large-scale farmers towards excessive mechanized farming, the overuse of fertilizers and pesticides, as well as the 
unsustainable water abstraction for irrigation purposes. Diffused pollution from these sources has also degraded the water quantity and quality, thereby compromising vital ecosystem services and disrupting the local and regional hydrological balance [2-5]. A study conducted in Portugal observed that of the total water used in agriculture, about $80 \%$ is for irrigation consumption [6].

In the future, pressures such as diffuse pollution or water abstraction are predicted to further increase [7-10], with climate change scenarios bringing great uncertainty to the water resources' availability. According to the Intergovernmental Panel on Climate Change (IPCC)'s Fifth Assessment Report [11], the Mediterranean climate, which is comprised of two contrasting seasons, i.e., the wet season with mild temperatures and the dry season with high temperatures, will show extreme variations due to climate change. This region will be highly affected by extreme events like droughts, floods and heat waves. These extreme events will greatly reduce the water availability, hydropower potential and crop productivity of the region. Additionally, health risks and the frequency of other stochastic events will also significantly increase.

The study area, i.e., the Sorraia River basin, also lies under the influence of the Mediterranean climate. This basin is greatly modified by anthropogenic activities such as the construction of dams and weirs to respond to residential, agricultural and industrial demands [12]. It has been predicted that climate change phenomena will further degrade the hydrological balance of the basin, leading to many socio-economic problems at both local and regional scales, further enhancing the water scarcity in the region. Hence, it is of utmost importance to accurately assess the impact of climate change on water resources to develop effective mitigation policies and a framework for management strategies. Better management strategies at the river basin level will not only maximize the benefits of irrigation and other anthropogenic modifications of the ecosystem but also minimize its impacts on water quantity and quality. Thus, the assessment of the impacts of climate change is essential to counter the effects of environmental stressors and improve the ecosystem equilibrium [13-17].

Hydrological models can forecast the outcomes of different management practices, thus providing guidance for water managers in defining cost-effective measures for future application [3,18-21]. Although there are many unforeseeable events, the use of models in river systems is accepted as a standard practice with relevant information derived from them $[4,19,22]$. A study carried out by Brito et al. [22] aimed at understanding the relationship between the eutrophication process of the downstream reservoir and soil erosion and nutrient losses related to flood events in a river basin (southern Portugal). Additionally, Mateus et al. [19] conducted an integrated study using basin and reservoir models to depict the influence of river basins on the eutrophication of downstream water bodies, obtaining results that allowed to test different management practices that affect the reservoir trophic status. Watershed modelling is also an important part of the Portuguese River Basin Management Plans at the national level [23]. However, no such records exist that consider the effect of climate change on water and nutrient dynamics in the Sorraia River catchment area through hydrological modelling. This constitutes a significant gap in terms of knowledge.

The aim of this study is to assess the impacts of climate change and management practices on the water quantity and quality of the Sorraia River using the hydrological model Soil Water Assessment Tool (SWAT) [24]. The main objective is to predict the effects of multiple biotic and abiotic stressors at the basin scale [3]. These stressors result from unsustainable anthropogenic activities and negatively affect the indicators of ecological quality and service. In addition, the study also has the following specific objectives:

(i) to simulate the baseline conditions in terms of hydrology and nutrients (N and $\mathrm{P})$ in the Sorraia River basin using the SWAT model [24];

(ii) to simulate three distinct storylines which combine alternative trends in the evolution of the society and practices with climate change scenarios;

(iii) to compare scenario results for accuracy and efficiency. 
The storylines and management scenarios considered in this study should serve as guidelines for defining mitigation measures in the catchment.

\section{Materials and Methods}

\subsection{Study Area}

This study was carried out in the Sorraia River (southern Portugal), the tributary of the Tagus River with the largest basin area, with $\sim 7730 \mathrm{~km}^{2}$ (Lat: $38.59^{\circ}$ to $39.50^{\circ}$; Long: $-8.99^{\circ}$ to $-7.24^{\circ}$ ), and with a longitudinal length of $\sim 155 \mathrm{~km}$ (Figure 1). The climate in the region is dry sub-humid, with dry and hot summers, and mild and wet winters. Records from 14 meteorological stations [25] for a 20-year period (1996 to 2015) showed that the annual precipitation in the region varied from 200 to $900 \mathrm{~mm}$, with the average of $\sim 500 \mathrm{~mm}$. The average monthly precipitation was $\sim 50 \mathrm{~mm}$, fluctuating up to $25 \mathrm{~mm}$ from April to September and $70 \mathrm{~mm}$ between October and March. The average annual surface air temperature was $\sim 15{ }^{\circ} \mathrm{C}$, varying from $\sim 9$ to $\sim 22^{\circ} \mathrm{C}$. The reference evapotranspiration estimated according to Allen et al. [26] reached $\sim 900 \mathrm{~mm}$. The dominant soil types found in the region are Cambisols, Luvisols, and Regosols [27]. Fluvisols are also found at higher concentrations in the downstream irrigated areas.

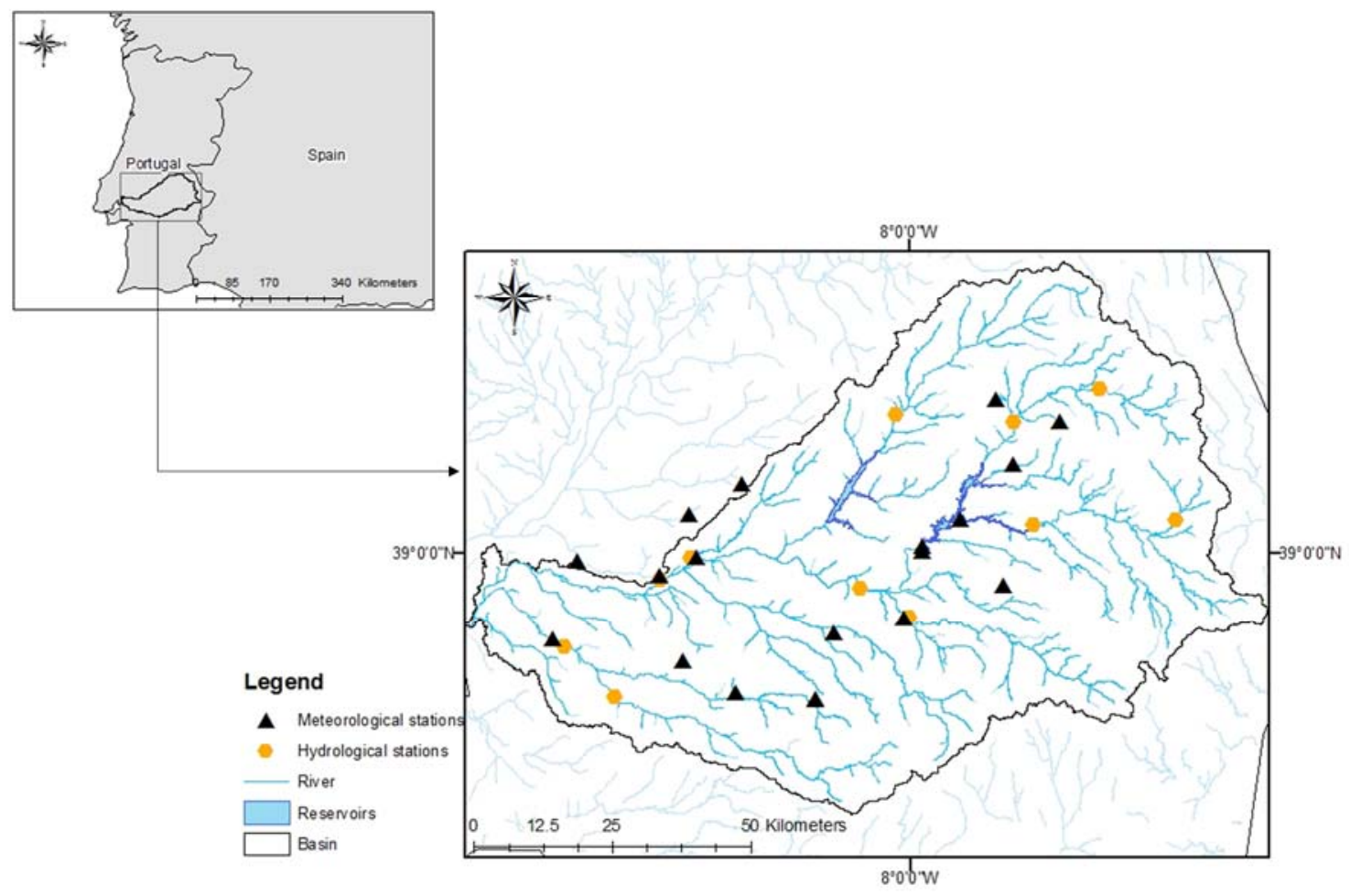

Figure 1. The Sorraia River Basin.

Two major reservoirs, Montargil and Maranhão, were built in the watershed during the second half of the twentieth century as a part of the Sorraia Valley Irrigation Implementation Plan. Currently, the Sorraia Valley is one of the largest irrigation areas in Portugal, totalizing 16,000 ha, in which corn (Zea mays L.), rice (Oryza sativa L.) and tomato (Solanum lycopersicum L.) predominate. The land use in the remaining area of the watershed is characterized by holm oak forest, rainfed cereals and pasture.

In terms of human population, the Sorraia watershed has a total of 153,100 inhabitants, with a density of 20 inhabitants $\mathrm{km}^{-2}$ [28]. The population is mainly concentrated in three core cities: Ponte de Sôr $(16,700$ inhabitants), Samora Correia $(17,123)$, and Coruche $(19,950)$. According to the River 
Basin Management Plan (RBMP [29]), hydro-morphological changes, diffuse pollution, municipal discharges, flow regulation, and water abstraction are the main pressures in the basin.

\subsection{Hydrological Modelling}

\subsubsection{The Soil and Water Assessment Tool (SWAT) Model}

The SWAT model [24] is widely used to simulate watershed processes [18,19,30-33]. SWAT is a semi-distributed watershed model focused on land management at a basin scale. The model splits the watershed into sub-basins that are assumed to be homogeneous in their Hydrologic Response Units (HRU), i.e., in terms of land use, soil and topographic characteristics. The relative straightforward formulation used in SWAT allows the model to run more demanding simulations within a reasonable time. The hydrology of the model is based on the daily water balance equation, as follows:

$$
\mathrm{SW}_{\mathrm{t}}=\mathrm{SW}_{0}+\sum_{\mathrm{i}=1}^{\mathrm{n}}\left(\mathrm{R}_{\text {day }}-\mathrm{Q}_{\text {surf }}-\mathrm{E}_{\mathrm{a}}-\mathrm{W}_{\text {seep }}-\mathrm{Q}_{\mathrm{gw}}\right)
$$

where $\mathrm{SW}_{\mathrm{t}}$ is the final soil water content $(\mathrm{mm}), \mathrm{SW}_{0}$ is the soil water content at the initial time step $(\mathrm{mm})$, $R_{\text {day }}$ is the daily precipitation (mm), $Q_{\text {surf }}$ is the surface runoff $(\mathrm{mm}), E_{a}$ is the actual evapotranspiration $(\mathrm{mm}), \mathrm{W}_{\text {seep }}$ is the percolated water $(\mathrm{mm})$, and $\mathrm{Q}_{\mathrm{gw}}$ is the return flow $(\mathrm{mm})$, all referring to day $\mathrm{i}$, which varies from 1 to the number of simulated days (n). In this study, the potential evapotranspiration rates were estimated using the Penman-Monteith method [26], with $\mathrm{E}_{\mathrm{a}}$ being then dependent on soil water availability. Surface runoff was computed from daily precipitation using a modification of the Soil Conservation Service Curve Number (SCS-CN) method [34]. Groundwater recharge was estimated by combining a storage routing technique and a crack-flow model. The lateral flow was simulated using a kinematic storage method [24].

The SWAT model can further simulate the nitrogen $(\mathrm{N})$ and phosphorus $(\mathrm{P})$ cycles. The $\mathrm{N}$ present in the soil is represented by five different pools, considering mineral and organic forms. The mineral $\mathrm{N}$ is divided into two pools: ammonia $\left(\mathrm{NH}_{4}{ }^{+}\right)$and nitrate $\left(\mathrm{NO}_{3}{ }^{-}\right)$. The organic $\mathrm{N}$ is divided into three pools: active, stable (associated to the humic substances) and fresh pool (associated to the crop residue). Molecular nitrogen is added naturally by biological and atmospheric nitrogen fixation. Anthropogenic activities and agricultural practices such as the use of fertilizers also act as sources of $\mathrm{N}$ in the environment. After fixation, $\mathrm{N}$ is converted to $\mathrm{NH}_{4}{ }^{+}$in the soil and then consumed by plants in the form of $\mathrm{NO}_{3}{ }^{-}$. Mineralisation is considered by the fresh organic pool associated with crop residues and the active pool associated with soil humus. At harvest, the remaining fraction of crop residues is incorporated into the first soil layer. $\mathrm{N}$ is removed from the soil through volatilisation, denitrification, erosion, and leaching (in the $\mathrm{NO}_{3}{ }^{-}$form). The total amount of $\mathrm{NH}_{4}{ }^{+}$ lost by volatilisation or nitrification is calculated considering the $\mathrm{NH}_{4}{ }^{+}$amount and environmental factors. The SWAT code calculates the denitrification process according to the soil carbon and nitrate source, a rate coefficient, and different environmental factors such as temperature and soil water content. The denitrification process occurs in anaerobic conditions. In the case of the phosphorus cycle, the model includes three inorganic $\mathrm{P}$ pools (solution, active, and stable) and three organic $\mathrm{P}$ pools (active, stable and fresh). The fresh organic pool is associated with crop residue and microbial biomass, while the active and stable organic pools are associated with the soil humus. The sum of the six pools represents total soil P. P is simulated considering the supply and demand during plant growth. Soluble and organic forms can be removed from the soil via mass flow (runoff). The amount of soluble P removed in runoff is predicted using solution P concentration in the top $10 \mathrm{~mm}$ of the soil profile, the runoff volume, and a partitioning factor. Sediment transport of $P$ is then simulated with a loading function [24].

In this study, the SWAT model was applied to the Sorraia basin using the ArcGIS extension from ESRI (Redlands, CA). The model application relied on available Geographical Information System maps for topography (SRTM), land use maps from Earth Observation (GSE Land M2.1) and soil maps 
and data from Cardoso et al. [35] (SROA). Daily discharge data provided by the reservoirs' manager (ARBVS-Farmers Association from the Sorraia Valley) were used in the model from 1996 to 2015. Meteorological time series were downloaded for the basin area from the National Water Resources Institute website (SNIRH). The input data considered for the present conditions (hereafter referred to as the baseline) are summarized in Table 1. In order to stabilize the model conditions, the period between 1996 and 2000 was considered as the warm-up period, and the baseline simulation was defined for the period 2001-2015.

Table 1. The input data used in the Soil Water Assessment Tool (SWAT) model application.

\begin{tabular}{cccc}
\hline Data Type & Source & Data Description & Resolution \\
\hline Topography & $\begin{array}{c}\text { Shuttle Radar Topography } \\
\text { Mission (SRTM) } \\
\text { NASA [36] }\end{array}$ & - & $90 \mathrm{~m}$ \\
\hline Soil type & Cardoso [35] & Soil physical properties & $1: 25,000$ \\
\hline Land Use & GSE Land M2.1 & Land use classification & $20 \mathrm{~m}$ and 300 m \\
Meteorology & $\begin{array}{c}\text { Serviço Nacional de Informação } \\
\text { dos Recursos Hídricos [25] }\end{array}$ & $\begin{array}{c}\text { Precipitation, temperature, } \\
\text { relative humidity and wind speed }\end{array}$ & Daily time series \\
\hline
\end{tabular}

\subsubsection{Calibration and Validation}

The SWAT model was calibrated by manually modifying one parameter at a time, considering the most sensitive parameters that determined the best results for simulating daily/monthly river flows. The hydrograms were analysed, and the parameters that affected flow peaks and baseflow were selected and modified until deviations between the model outputs and measured flow data were minimised (Table 2). The previously calibrated parameters were then validated by comparing the results of the simulations with an independent dataset. Model calibration was thus performed for the period between 2001 and 2006, while the validation exercise was carried out from 2006 to 2015.

Table 2. The values of the calibrated parameters used in the SWAT model (parameter, description and default according to Neitsch et al. [24]).

\begin{tabular}{|c|c|c|c|}
\hline Parameter & Description & Default & Calibrated Value \\
\hline $\mathrm{CN} 2$ & $\begin{array}{l}\text { SCS runoff curve number } \\
\text { for moisture condition II. }\end{array}$ & 25 to 92 & 80 to 92 \\
\hline ALPHA_BF & $\begin{array}{l}\text { Baseflow alpha factor } \\
(1 / \text { days }) .\end{array}$ & 0.048 & 1 \\
\hline GW_Delay & $\begin{array}{l}\text { Groundwater delay time } \\
\text { (days). }\end{array}$ & 31 & 3 \\
\hline SOL_AWC & $\begin{array}{c}\text { Available water capacity } \\
\text { of the soil layer (mm } \\
\mathrm{H}_{2} \mathrm{O} / \mathrm{mm} \text { soil). }\end{array}$ & $0.11-0.14$ & $-40 \%$ \\
\hline SOL_ZMX & $\begin{array}{l}\text { Maximum rooting depth } \\
\text { of soil profile. (mm). }\end{array}$ & - & 500 \\
\hline SOL_Z1 & $\begin{array}{l}\text { Depth from the soil } \\
\text { surface to the bottom of } \\
\text { the first layer }(\mathrm{mm}) \text {. }\end{array}$ & 300 to 800 & $\begin{array}{c}\text { slope } 0-3 \% \text {, to } 800 \\
\text { slope } 3-8 \% \text {, to } 500 \\
\text { slope } 8-9999 \% \text {, to } 300\end{array}$ \\
\hline SOL_Z2 & $\begin{array}{l}\text { Depth from the soil } \\
\text { surface to the bottom of } \\
\text { the second layer ( } \mathrm{mm}) \text {. }\end{array}$ & 300 to 800 & $\begin{array}{c}\text { slope } 0-3 \% \text {, to } 1000 \\
\text { slope } 3-8 \% \text {, to } 800 \\
\text { slope } 8-9999 \% \text {, to } 500\end{array}$ \\
\hline
\end{tabular}

Discharge data from two monitoring stations were used for model calibration and validation. Moinho Novo (Lat. 39.228 ${ }^{\circ}$ Long. $-8.029^{\circ}$ ) and Ponte Vila Formosa (Lat. 39.216 ${ }^{\circ}$ Long. $-7.784^{\circ}$ ) 
were selected as they are not significantly influenced by the operation of existing hydraulic structures. To evaluate the nutrients' concentration, the monitoring station at Ponte de Coruche $\left(38.956^{\circ} ;-8.524^{\circ}\right)$ was considered [25]. However, its location and the monitoring interval of measured values (usually 15 days to 1 month) hindered the representativeness of the monitoring record.

The goodness-of-fit indicators adopted for comparing model outputs with measured flow data were the coefficient of determination $\left(\mathrm{R}^{2}\right)$, the root mean square error (RMSE), the Nash-Sutcliffe model efficiency coefficient (NSE [37]), and the Model Bias (Bias). An $\mathrm{R}^{2}$ value close to 1 indicates that the model explains the variance of observations well. RMSE values close to zero indicate small estimation errors and good model predictions. Bias was defined as the average difference between the estimator and the true value. Bias values close to zero indicate no under or over-estimation of the measured results. NSE values close to 1 indicate a perfect match of modelled discharge to the observed data, hence, indicating that the model predictions are good. On the contrary, when NSE is very close to 0 or negative, there is no gain in using the model.

For $\mathrm{N}$ and $\mathrm{P}$, comparison was focused on the magnitude of the simulated and observed values due to data limitation, considering only $\mathrm{R}^{2}$ and Bias indicators.

\subsubsection{Storylines}

The storylines defined in this study followed the framework developed within the Managing Aquatic Ecosystems and Water Resources Under Multiple Stress Project-MARS [3,38]. Here, the storylines are defined as a combination of societal and climate scenarios. Three storylines were considered by combining the work of O'Neill et al. [39] and Riahi et al. [14]. These authors defined Shared Socioeconomic Pathways (SSP's) as reference scenarios describing plausible alternative trends in the evolution of society and ecosystems over a century timescale in the absence of climate change or climate policies. Storylines also considered Moss et al. [40] who developed Representative Concentration Pathways (RCPs) for greenhouse emissions. RCP 4.5 assume that greenhouse gas emissions will peak around 2040 followed by a decline, while RCP 8.5 considers that emissions will increase throughout the 21st century.

Climate data considered in this study, such as the surface air temperature and precipitation, was extracted from the Inter-Sectoral Impact Model Intercomparison (ISI-MIP) project as it provided the best temporal and spatial resolution for the study area. In the ISI-MIP project, the bias-corrected time-series of surface air temperature and precipitation were downscaled at a $0.5^{\circ}$ resolution [41]. Following the IPCC's Fifth Assessment Report, the ISI-MIP project run specific climate models to obtain data [42], which included five of the Coupled Model Intercomparison Project Phase 5 (CMIP5) Global circulation models (GFDL-ESM2M, HadGEM2-ES, IPSL-CM5A-LR, MIROC-ESM-CHEM and NorESM1-M).

As established by Faneca et al. [43] and Birk et al. [44], the storylines considered in this study are the following (Figure 2):

Storyline 1 (STL1): Techno World. It represents fast global economic growth, characterised by a rapid technological development but with high energy demands and no real drive to enhance or ignore the health of natural ecosystems. This world is based on a combination of SSP-5 which consider a conventional development and low population [39] and climate scenario RCP 8.5 [40];

Storyline 2 (STL2): Consensus world. It is a world in which the actual policies continue after 2020. The growth of economy keeps to the same pace as now, but with awareness for environment preservation. This world is based on a combination of SSP-2 which is considered as the intermediate stage [39] and the climate scenario RCP 4.5 [40];

Storyline 3 (STL3): Survival of the fittest. It represents a fragmented world, driven by the individual interest of countries, with fast economic growth in NW Europe but with recessions in other regions; with minimal or no investment and effort in environmental protection, conservation and restoration. This world is based on a combination of SSP-3, which consider a rapid technology for fossils, high demand and high economic growth [39] and climate scenario RCP 8.5 [40]. 


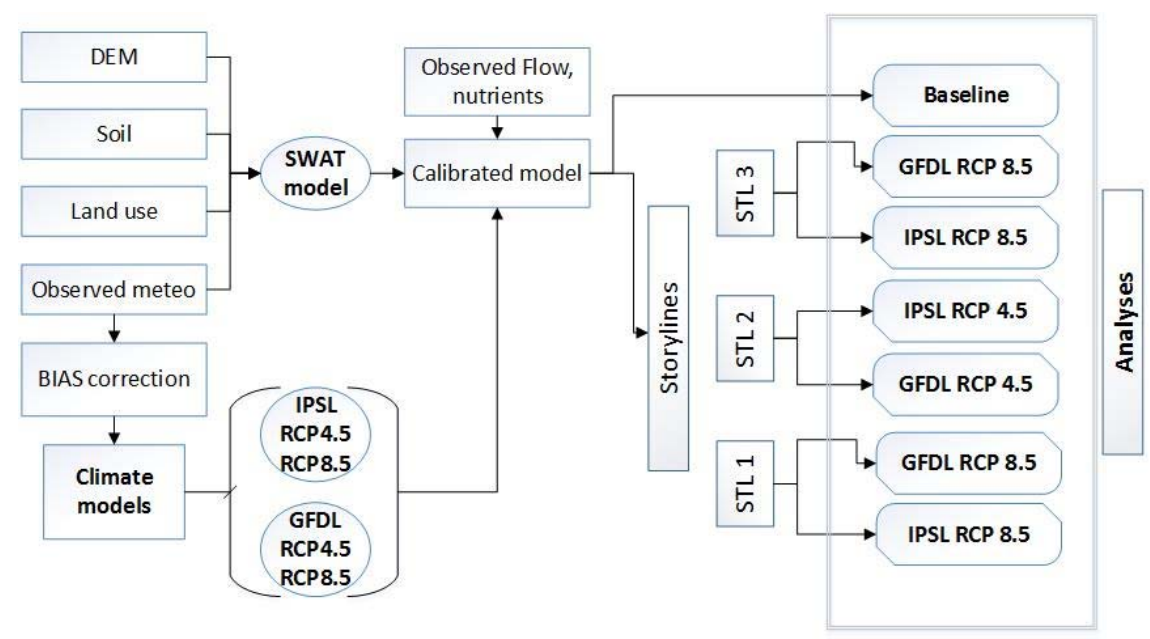

Figure 2. The schematic description of the modelling approach and considered scenarios (IPSL, IPSL-CM5A-LR model; GFDL, GFDL-ESM2M model; RCPs, Representative Concentration Pathways, STL, storylines).

The two climate models adopted for each climate scenario (Figure 2) were:

GFDL-ESM2M [45,46]: RCP 4.5 was used in Storyline 2 (hereafter referred as STL2 GFDL), and RCP8.5 was used in Storyline 1 (STL1 GFDL) and Storyline 3 (STL3 GFDL);

IPSL-CM5A-LR [47]: RCP 4.5 was used in Storyline 2 (STL2 IPSL), and RCP8.5 was used in Storyline 1 (STL1 IPSL) and Storyline 3 (STL3 IPSL).

GFDL and IPSL were adopted in this study as they give results close to the ISI-MIP median for the Western Europe region [43]. These two models differ in terms of the atmospheric prognostic state and of the spatial resolution of their atmospheric grid $\left(2.5^{\circ}\right.$ lon. by $2.0^{\circ}$ lat. for GFDL, and $2.5^{\circ}$ lon. by $3.75^{\circ}$ lat. for IPSL). Further conceptual differences between the GFDL and IPSL models, and the downscaling of variables at the basin-scale acquired from the outputs of these two models are given in Warszawski et al. [41] and references therein. Bias-corrected time-series of air temperature and precipitation downscaled at a $0.5^{\circ}$ resolution [48] were considered. Additional bias correction for the Sorraia basin was applied on precipitation (Figure 3) and surface air temperature (Figure 4) values following Shrestha [49] and Shrestha et al. [50] and considering the measured data from 2006-2015. This is a statistical downscaling method known as Linear scanning bias correction based on the average difference between monthly observed and historical time series for the same period.

Two distinct temporal intervals were set up to run the simulations: 2030 (defined as a 10-year average from 2025 to 2034) and 2060 (defined as a 10-year average from 2055 to 2064). Thus, the term "climate change" refers here only to decadal changes. The period 1996-2015 was selected as a reference for the baseline simulation (present condition).
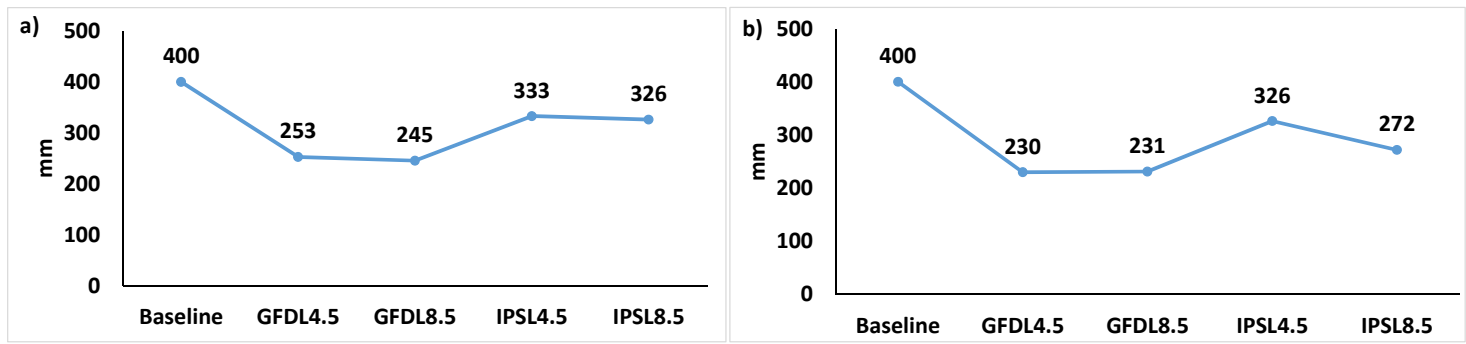

Figure 3. The annual average precipitation $(\mathrm{mm})$ for the baseline conditions and climate scenarios: (a) timeline 2030; (b) timeline 2060. For clarification on the modelled scenarios, please see Figure 2. 
a)

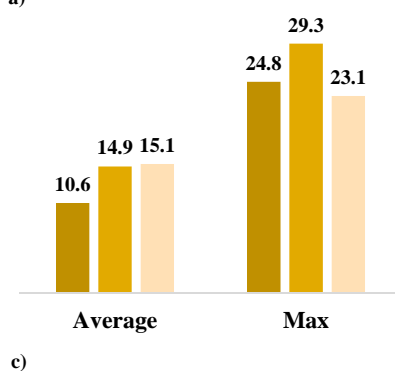

c)
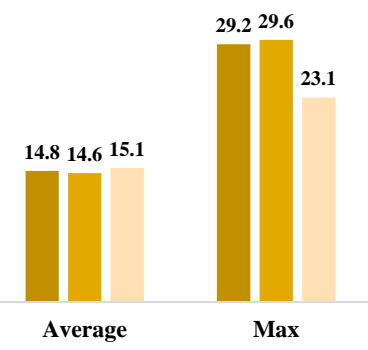

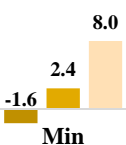

b)

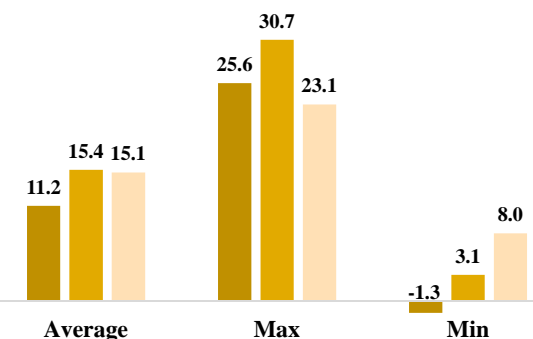

d)
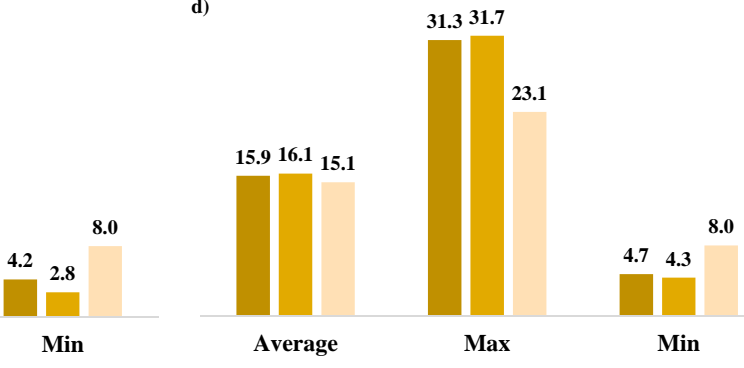

GFDL4.5 GFDL8.5 Baseline

Figure 4. The average, maximum, and minimum daily temperature $\left({ }^{\circ} \mathrm{C}\right)$ for the present conditions (baseline) and climate scenarios: (a) and (c) timeline 2030; (b) and (d) timeline 2060. For clarification on the modelled scenarios, please see Figure 2.

The downscaling of the socio-economic factors and foreseen management practices change in the Sorraia catchment was performed with the help of local water board stakeholders (Associação de Regantes e Beneficiários do Vale do Sorraia). Therefore, each storyline was naturally translated into quantitative data assuming that the Mediterranean climate imposes additional stress on the agriculture [43]. This additional stress was defined in terms of management practice changes, namely on the amount of fertilizer and irrigation applied to crops (Table 3). That assumption considered that in a changing environment, with temperatures increasing, higher irrigation needs are required to fulfil crop requirements. Additionally, higher temperatures lead to higher mineralisation rates and, thus, higher use of fertilizers. It also considered that higher usage of fertilizers and irrigation lead to larger diffuse pollutions from agricultural fields and greater environmental risk. Model inputs were thus related to the level of agriculture intensification and the environmental protection awareness considered in each Storyline. Fertilizers were applied to prevent nutrient stress by plants. The percentage variation (increase or decrease) defined in Table 3 for each storyline and timeline was applied on the baseline values and used as an input in the model.

Table 3. The input values used for simulating the storylines in the Soil Water Assessment Tool (SWAT).

\begin{tabular}{|c|c|c|c|c|c|}
\hline Storyline & Timeline & Management Practices & Variation $(\%)$ & Baseline & Amount \\
\hline & 2030 & \multirow{2}{*}{ Fertilization (kg/ha) } & $10+$ & \multirow{2}{*}{492} & 541 \\
\hline & 2060 & & $15+$ & & 566 \\
\hline \multirow[t]{4}{*}{ STL1 } & 2030 & \multirow{2}{*}{ Irrigation (mm) } & $10-$ & \multirow{2}{*}{430} & 387 \\
\hline & 2060 & & $15-$ & & 366 \\
\hline & 2030 & \multirow{2}{*}{ Fertilization (kg/ha) } & $10-$ & \multirow{2}{*}{492} & 443 \\
\hline & 2060 & & $15-$ & & 418 \\
\hline \multirow[t]{4}{*}{ STL2 } & 2030 & \multirow{2}{*}{ Irrigation (mm) } & $20-$ & \multirow{2}{*}{430} & 344 \\
\hline & 2060 & & $25-$ & & 323 \\
\hline & 2030 & \multirow{2}{*}{ Fertilization (kg/ha) } & $30+$ & \multirow{2}{*}{492} & 640 \\
\hline & 2060 & & $35+$ & & 664 \\
\hline \multirow[t]{2}{*}{ STL3 } & 2030 & \multirow{2}{*}{ Irrigation (mm) } & $30+$ & \multirow{2}{*}{430} & 559 \\
\hline & 2060 & & $35+$ & & 581 \\
\hline
\end{tabular}




\section{Results and Discussion}

\subsection{Model Calibration/Validation}

Model calibration was carried out considering the period between 2001 and 2006, and validation was performed considering the period between 2006 and 2015. The statistical indicators obtained after comparing the daily and monthly simulated and measured flow values at the selected monitored stations are presented in Table 4 . At Moinho Novo, the $\mathrm{R}^{2}$ value of 0.71 for monthly data shows that a considerable proportion of variability of the observed data was explained by the model (Table 4 and Figure 5). The RMSE value of $6 \mathrm{~m}^{3} /$ month indicates a small error of model estimates, while the NSE value of 0.71 indicates that the residual variance results were much smaller than the measured data variance (Table 4 and Figure 5). The comparison of daily values produced, as expected, worse results, with errors being mostly minimized during the monthly analysis due to data aggregation. For the validation period, the indicators were found to be similar, indicating a reasonable calibration of model parameters when considering all the uncertainties related to measurements.

Table 4. The daily and monthly flow statistics at Moinho Novo and Ponte Vila Formosa.

\begin{tabular}{ccccccccc}
\hline \multirow{2}{*}{ Statistics } & \multicolumn{4}{c}{ Moinho Novo } & \multicolumn{3}{c}{ Ponte Vila Formosa } \\
\cline { 2 - 9 } & \multicolumn{2}{c}{ Calibration } & \multicolumn{2}{c}{ Validation } & \multicolumn{2}{c}{ Calibration } & \multicolumn{2}{c}{ Validation } \\
\cline { 2 - 9 } & Daily & Monthly & Daily & Monthly & Daily & Monthly & Daily & Monthly \\
\hline Obs. Average & 6.05 & 6.71 & 7.57 & 7.07 & 3.17 & 3.31 & 5.68 & 5.61 \\
Mod. Average & 6.95 & 7.04 & 6.50 & 5.81 & 6.09 & 6.27 & 5.22 & 5.19 \\
Bias & 0.90 & 0.33 & -1.07 & -1.27 & 2.93 & 2.97 & -0.46 & -0.42 \\
RMSE $_{\mathbf{R}^{\mathbf{2}}}$ & 13.1 & 6.00 & 16.6 & 7.51 & 12.61 & 6.04 & 15.21 & 5.93 \\
Model Efficiency & 0.41 & 0.71 & 0.41 & 0.68 & 0.31 & 0.58 & 0.24 & 0.54 \\
\hline
\end{tabular}
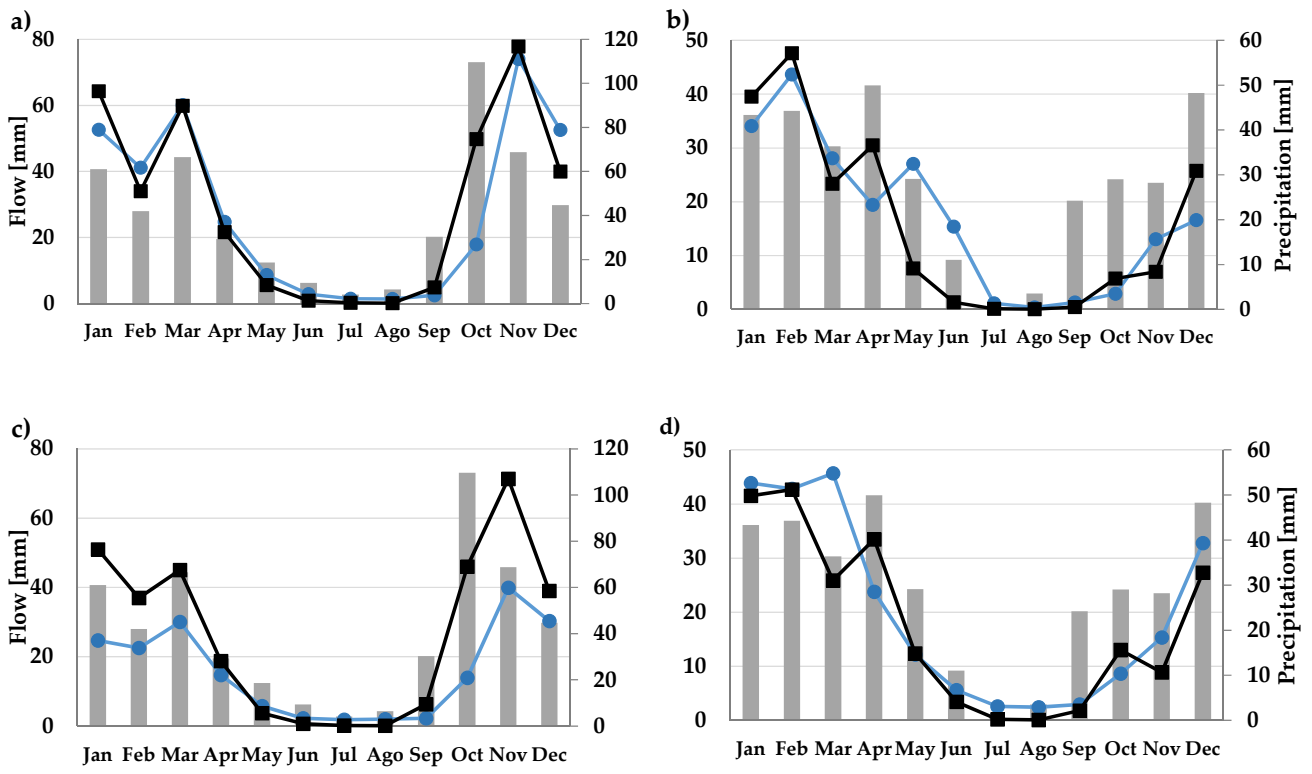

Precipitation - -Measurements $\rightarrow$-Simulated

Figure 5. The monthly average flow ( $\mathrm{mm}$ ) in Moinho Novo: (a) calibration period; (b) validation period; and Ponte Vila Formosa location; (c) calibration period; (d) validation period.

At Ponte Vila Formosa, the statistical indicators found for the calibration and validation periods were similar to those obtained at Moinho Novo. The exception was the negative NSE value computed for daily values, which suggests that the average of observed values has a larger predictive power than the model results. Nonetheless, the NSE statistics computed from monthly values are positive 
and the average monthly flows have a behaviour similar to the measured data (Figure 5). For $\mathrm{N}$ and $\mathrm{P}$, no calibration was carried out due to the data limitation with the default parameters of the SWAT model being considered. The evaluation of model outputs focused on its ability to reproduce the order of magnitude and the peaks of the measured values, which proved that the model is able to offer reasonable results. For the Total $\mathrm{N}$ at Ponte de Coruche, the following statistical indicators from the comparison between simulated and measured concentrations were obtained: $R^{2}=0.59$; Bias $=0.22 \mathrm{mgN} \mathrm{L}^{-1}$. For the Total $\mathrm{P}$, the following statistical indicators were also obtained: $\mathrm{R}^{2}=0.14$; Bias $=-0.067 \mathrm{mgP} \mathrm{L}^{-1}$.

\subsection{Scenario Analysis}

\subsubsection{Water Quantity}

After calibration and validation, the SWAT model was used to evaluate the developed storylines. Climate models showed a decrease in precipitation from $400 \mathrm{~mm}^{-1 e a r^{-1}}$ to an average of $264 \mathrm{~mm}$ year $^{-1}$ on both timelines (Figure 6). As a result, the simulated scenarios showed a substantial reduction of monthly flows for the 2030 and 2060 timelines (Figure 7). Flow reduction evidenced a non-linear relationship between precipitation and monthly river flow averages. This resulted from the uncertainty associated with climate models, particularly in the forecast of extremes events (Figure 6). The monthly average flow for the baseline simulation was $42 \mathrm{~m}^{3} \mathrm{~s}^{-1}$ (Table 5), while the IPSL model showed a decrease by half of this value in the timeline 2030 (to about $19 \mathrm{~m}^{3} \mathrm{~s}^{-1}$ ), and a further decrease in the timeline 2060 (to $10 \mathrm{~m}^{3} \mathrm{~s}^{-1}$ ). More severe results were obtained with the GFDL model for the same scenarios, predicting a decrease in the precipitation average to half of the present value, which resulted in monthly flow averages of $4.5 \mathrm{~m}^{3} \mathrm{~s}^{-1}$ and $2.5 \mathrm{~m}^{3} \mathrm{~s}^{-1}$ for the timelines 2030 and 2060, respectively (Table 5). Moreover, the increasing temperature trend predicted by both climate models combined with decreasing precipitation further led to more hazardous agricultural practices for the environment, with irrigation and fertilizer requirements increasing as considered in STL1 and STL3. Even for the scenario with more sustainable agricultural practices (STL 2), the changes in the climate variables had the same severe effect on river flow (Figure 5). For both climate scenarios, the decrease in irrigation in STL2 resulted in small differences in the monthly flow average when compared with the previous results (Table 5).

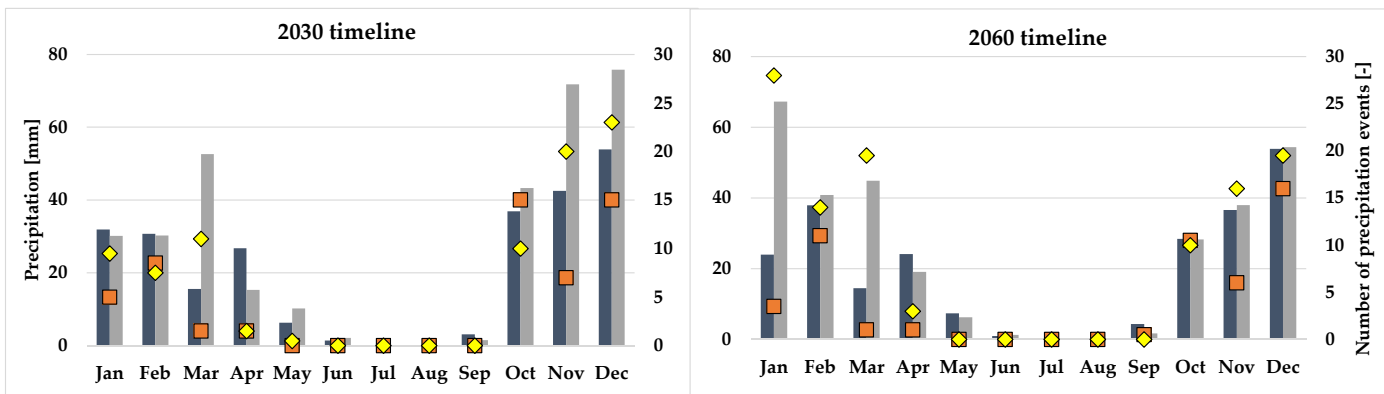

Figure 6. The monthly average precipitation $(\mathrm{mm})$ for each climate model (bars), and the number of daily precipitation events $>10 \mathrm{~mm}(-)$ for all period (symbols), for each timeline.

Table 5. The monthly averages for river flow $\left(\mathrm{m}^{3} \mathrm{~s}^{-1}\right)$, total $\mathrm{N}\left(\mathrm{mg} \mathrm{N} \mathrm{L}^{-1}\right)$, and total $\mathrm{P}\left(\mathrm{mg} \mathrm{P} \mathrm{L}^{-1}\right)$ in each scenario.

\begin{tabular}{|c|c|c|c|c|c|c|c|c|c|c|c|c|c|}
\hline \multirow{2}{*}{ Monthly Average } & \multirow{2}{*}{ Baseline } & STL1 & STL2 & STL3 & STL1 & STL2 & STL3 & STL1 & STL2 & STL3 & STL1 & STL2 & STL3 \\
\hline & & \multicolumn{3}{|c|}{2030 GFDL } & \multicolumn{3}{|c|}{2030 IPSL } & \multicolumn{3}{|c|}{2060 GFDL } & \multicolumn{3}{|c|}{2060 IPSL } \\
\hline River flow $\left(\mathrm{m}^{3} \mathrm{~s}^{-1}\right)$ & 42.3 & 4.1 & 4.5 & 4.1 & 18.8 & 18.2 & 18.8 & 2.5 & 2.6 & 2.5 & 8.4 & 9.7 & 9.8 \\
\hline Total N $\left(\mathrm{mg} \mathrm{N} \mathrm{L}^{-1}\right)$ & 0.7 & 3.3 & 2.2 & 3.9 & 1.1 & 0.9 & 1.2 & 5.5 & 2.6 & 6.2 & 1.4 & 1.2 & 1.5 \\
\hline Total P (mg P L $\left.{ }^{-1}\right)$ & 0.2 & 0.1 & 0.1 & 0.1 & 0.3 & 0.3 & 0.4 & 0.2 & 0.2 & 0.2 & 0.2 & 0.2 & 0.2 \\
\hline
\end{tabular}



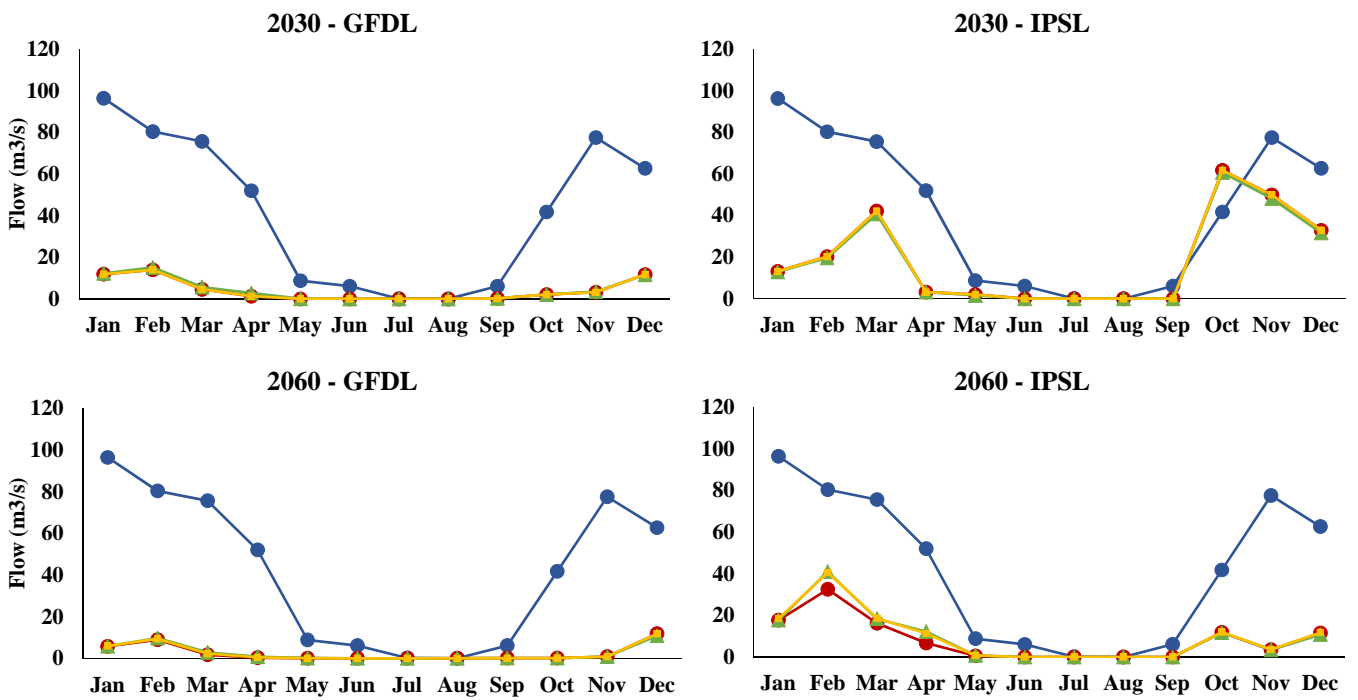

Figure 7. The monthly average of modelled river flow $\left(\mathrm{m}^{3} \mathrm{~s}^{-1}\right)$ for each storyline and baseline. For clarification on the modelled scenarios, please see Figure 2.

The simulated storylines focused on distinct management practices in the watershed. Changes were associated with climate change models IPSL and GFDL developed for this purpose. All simulated scenarios showed a significant decrease in water quantity, clearly visible in the reduction of river flow (Figure 7). This outcome was a direct consequence of the significant decrease in precipitation generally estimated by all climate models, especially for Mediterranean countries, due to the increased anticyclonic circulation that yields increasingly stable conditions, and to a northward shift of the Atlantic storm track [11,51,52]. Similarly, Bucak et al. [53] predicted flow variations between +18 and $-59 \%$ for the Beyşehir watershed (Turkey), depending on the climate scenario considered. Pascual et al. [54] reported the largest reductions (34\%) in mean streamflows (for 2076-2100) to be expected in the headwaters of two humid catchments in Catalonia (Spain), while lesser variations ( $25 \%$ of mean value for 2076-2100) were to be expected in a drier area. Additionally, in all three catchments, the most notable projected decreases in streamflow were observed in autumn (50\%) and summer $(30 \%)$. The largest reductions in the Sorraia river flow were associated with agriculture activities, namely irrigation, which, combined with climatic change, augmented the problem. Therefore, while water availability in several Mediterranean basins is mostly conditioned by precipitation, the results of this study in the Sorraia River basin show that other processes related to agricultural practices also contribute to water scarcity, such as evapotranspiration and irrigation.

\subsubsection{Water Quality}

In the Sorraia basin, irrigated crops are traditionally sown during mid-April/May and harvested in mid-September/October [55,56]. This leads to an increase of Total N concentration in the Sorraia River during those periods as noticed in all storylines, especially in STL3 (Table 5 and Figure 8), which results from the water reduction in the basin and increased use of fertilizers (STL1 and STL3). Total N concentrations were perceptibly higher when using the GFDL climate model due to the lower precipitation amount predicted. An increase of the total $\mathrm{N}$ concentration in the river during the crop growth periods was also predicted due to nutrient runoff and leaching. The most marked increase was observed immediately after the harvest season (Figure 8), coinciding with the mineralisation of crop residues and the beginning of the rainy seasons. The increase of soil water content further promoted nitrate leaching, as well as losses by the lateral flow. Therefore, precipitation reduction played a fundamental role in the future projections of catchment dynamics. 
Jan Feb Mar Apr May Jun Jul Aug Sep Oct Nov Dec Month

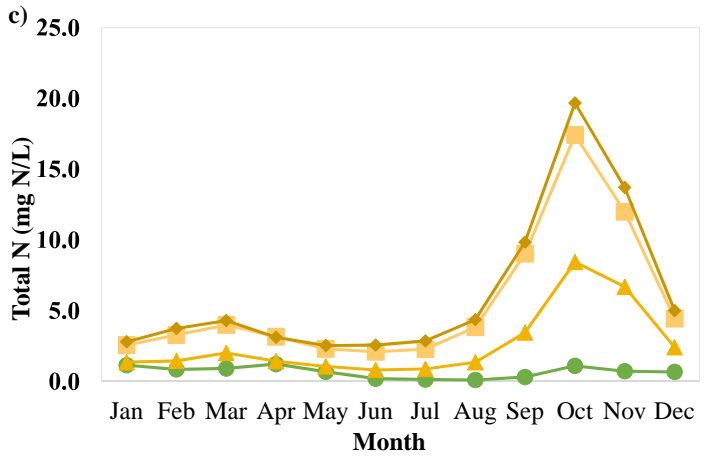

b) 3.5

3.0

2.5

2.0

1.5

1.0

0.5

Jan Feb Mar Apr May Jun Jul Aug Sep Oct Nov Dec Month

d) 3.5

3.0

2.5

2.0

1.5

1.0

0.5

$\mathbf{0 . 0}$

Jan Feb Mar Apr May Jun Jul Aug Sep Oct Nov Dec Month

-Baseline - STL1 $\rightarrow$ STL2 $\rightarrow$ STL3

Figure 8. The monthly average of modelled Total $\mathrm{N}$ concentration $\left(\mathrm{mg} \mathrm{N} \mathrm{L}^{-1}\right)$ for each storyline and baseline period: (a) 2030-GFDL; (b) 2060-GFDL; (c) 2030-IPSL; (d) 2060-IPSL. For clarification on the modelled scenarios, please see Figure 2.

The increase of Total $\mathrm{N}$ concentration in all storylines was drastic when compared with the present conditions ( $0.7 \mathrm{mg} \mathrm{N} \mathrm{L}^{-1}$ ) (Table 5). For the GFDL scenarios, despite the agriculture practices outlined in STL2, there was a predicted increase of Total $\mathrm{N}$ concentration in the Sorraia River up to $2.2 \mathrm{mg} \mathrm{N} \mathrm{L}^{-1}$ in the 2030 timeline, and up to $2.6 \mathrm{mg} \mathrm{N} \mathrm{L}^{-1}$ in the 2060 timeline. For the STL1 and STL3, an average of $3.6 \mathrm{mg} \mathrm{N} \mathrm{L}^{-1}$ was computed for the timeline 2030, and an average of $5.9 \mathrm{mg} \mathrm{N} \mathrm{L}^{-1}$ was computed for the timeline 2060. For the IPSL model scenarios, the increase was not so outstanding, especially for STL2, where the monthly averages in the timelines of 2030 and 2060 were predicted to be 0.9 and $1.2 \mathrm{mg} \mathrm{N} \mathrm{L}^{-1}$, respectively. For this model, an average of $1.2 \mathrm{mg} \mathrm{N} \mathrm{L}^{-1}$ was observed for the STL1 and STL3 in the timeline 2030, and an average of $1.4 \mathrm{mg} \mathrm{N} \mathrm{L}^{-1}$ was noted for the timeline 2060 (Table 5).

The projected increase of $\mathrm{N}$ concentration in the river resulted from the progressive use of this nutrient as fertilizer in most scenarios, but also as a consequence of natural processes occurring in the soils. This outcome is also visible in the more optimistic scenario (STL2), where the negative impact of water flow reductions on water quality was also high. Nitrate was the most abundant form of $\mathrm{N}$ simulated in the river (Figure 9), also contributing significantly towards this outcome were nitrate high solubility and leaching susceptibility $[57,58]$, mostly during the periods of higher precipitation, and the type of fertilizers used by farmers [59].

The most pronounced increase in the nutrients concentration was found to occur during the autumn/winter period, after the harvesting of corn in irrigated areas (September/October). The high temperature and low soil moisture values predicted during this time of the year enhanced the mineralization of crop residues as observed by the increase of simulated organic $\mathrm{N}$ in the river (Figure 9). Nitrite was the least abundant form of $\mathrm{N}$ as its oxidation process occurred very fast. The significant increase in $\mathrm{N}$ and $\mathrm{P}$ may enhance the eutrophication process, thus contributing towards the degradation of water quality [22]. 

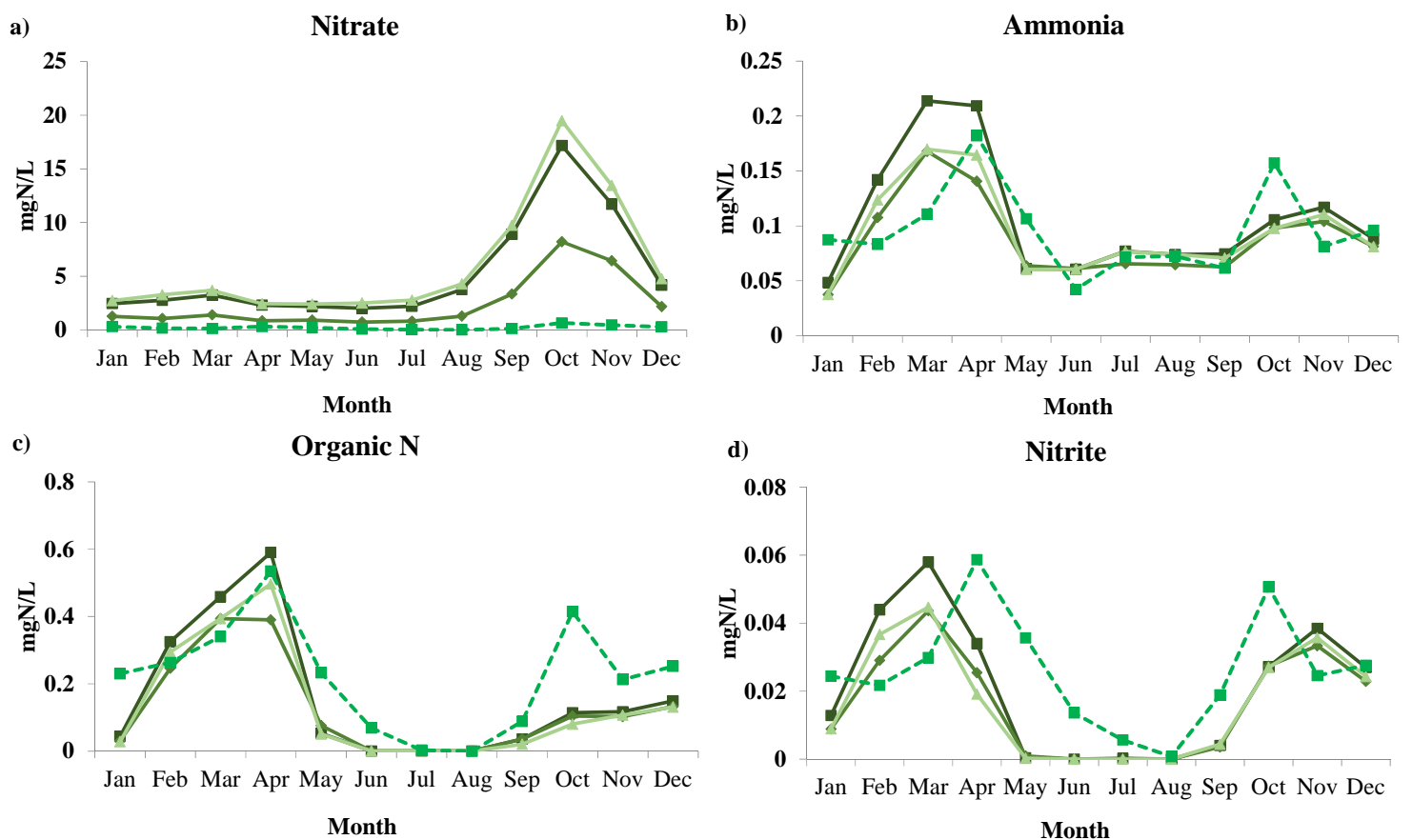

Month

Month

$-\square$-Baseline $\rightarrow$-Storyline $1 \multimap$ Storyline $2 \multimap$ Storyline 3

Figure 9. The monthly evolution of the $\mathrm{N}$ forms $\left(\mathrm{mg} \mathrm{N} \mathrm{L}^{-1}\right)$ for each storyline (timeline 2060 and GFDL climate model) and baseline condition: (a) Nitrate; (b) Ammonia; (c) Organic N; and (d) Nitrite.

Table 5 and Figure 10 further describe the monthly behaviour of the Total P concentrations in the baseline simulation and future scenarios while considering the different Storylines and climate models. On average, most of the scenarios led to similar monthly concentrations when compared with the present $\left(0.2 \mathrm{mg} \mathrm{P} \mathrm{L}^{-1}\right)$. In the 2030 timeline, a decrease of the Total $\mathrm{P}$ concentration in the Sorraia River to $0.1 \mathrm{mg} \mathrm{P} \mathrm{L}^{-1}$ was predicted for all storylines when using the GFDL model, mainly due to the significant decrease in the precipitation amount which reduced runoff and soil erosion, thus decreasing the transport capacity of $\mathrm{P}$ in the basin. In the 2060 timeline, an increase of the Total P concentration to $0.3 \mathrm{mg} \mathrm{P} \mathrm{L}^{-1}$ in the STL 1 and STL2, and a double-fold increase $\left(0.4 \mathrm{mg} \mathrm{P} \mathrm{L}^{-1}\right)$ in the STL3 were predicted, in line with the literature [60]. Serpa et al. [60] found a similar decrease of water quality in the Vale do Gaio River (Portugal), located a few kilometres south of the Sorraia River basin, with $\mathrm{P}$ concentrations increasing from $+29 \%$ to $+93 \%$ depending on the storylines adopted. All climate models and Storylines showed the same concentration averages for the 2060 timeline when comparing with the present monthly average $\left(0.2 \mathrm{mg} \mathrm{P} \mathrm{L}^{-1}\right)$. However, the major differences observed between the results from GFDL and IPSL climate models may result from extreme precipitation events as shown above (Figure 7).

Interestingly, the mineral P increase resulting from fertilizer use in corn fields was not obvious in terms of water quality results. This outcome can be explained by the fact that $P$ presents low mobility, adsorbing to sediments and depending on rainfall and runoff events to be removed from agricultural fields. As shown in Figures 10 and 11, P concentrations are expected to exhibit a different behaviour from $\mathrm{N}$ in all storylines. However, the fact that $\mathrm{P}$ concentrations show a slight increase despite the decrease in precipitation suggests that its continued application will have a significant impact on water quality. 
a) 0.6

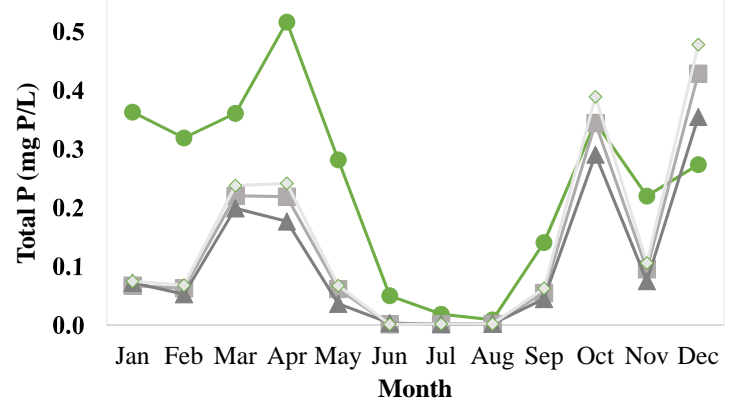

c) 0.6

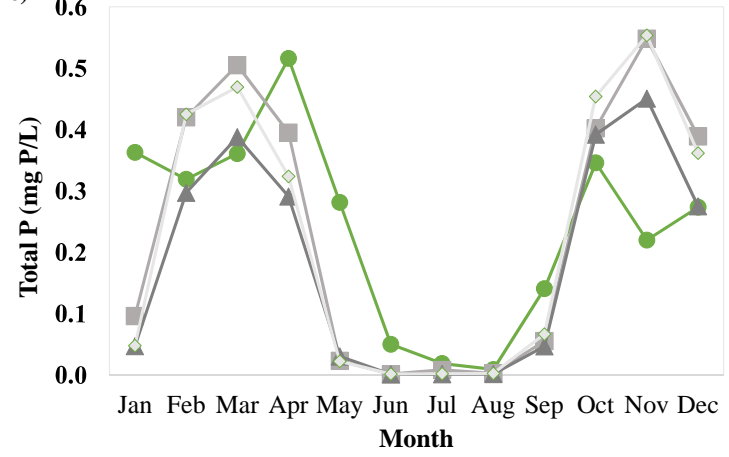

b)

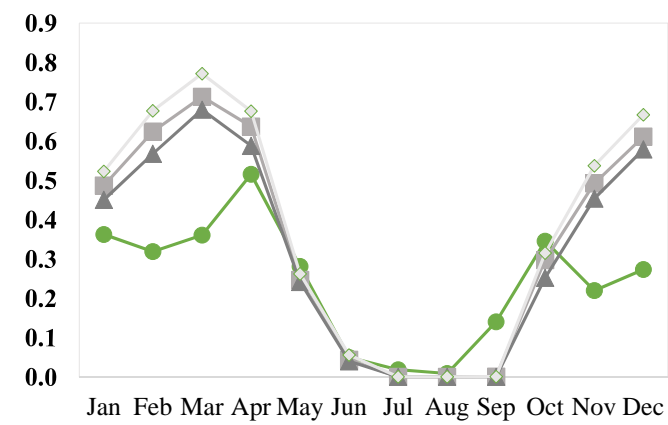

Jan Feb Mar Apr May Jun Jul Aug Sep Oct Nov Dec Month

d) 0.6

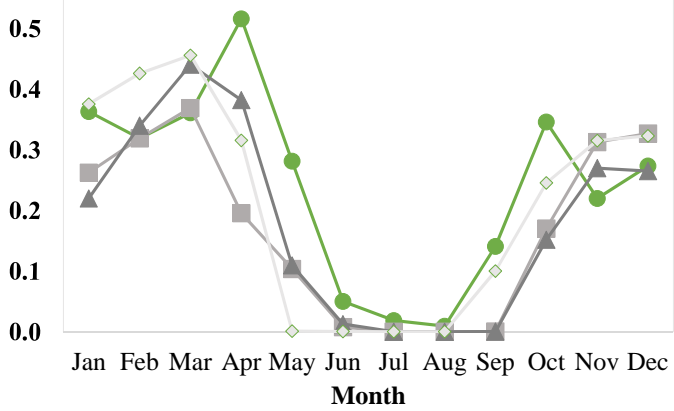

- - Baseline - STL1 $\leftarrow$ STL2 $\diamond$ STL3

Figure 10. The monthly average of the modelled Total $\mathrm{P}$ concentration $\left(\mathrm{mg} \mathrm{P} \mathrm{L}^{-1}\right)$ for each storyline and baseline: (a) 2030-GFDL; (b) 2060-GFDL; (c) 2030-IPSL; (d) 2060-IPSL. For clarification on the modelled scenarios, please see Figure 2.

a)

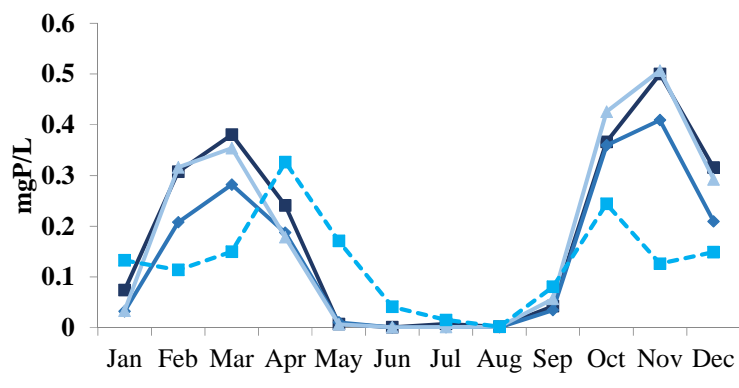

Month b) Organic $\mathbf{P}$

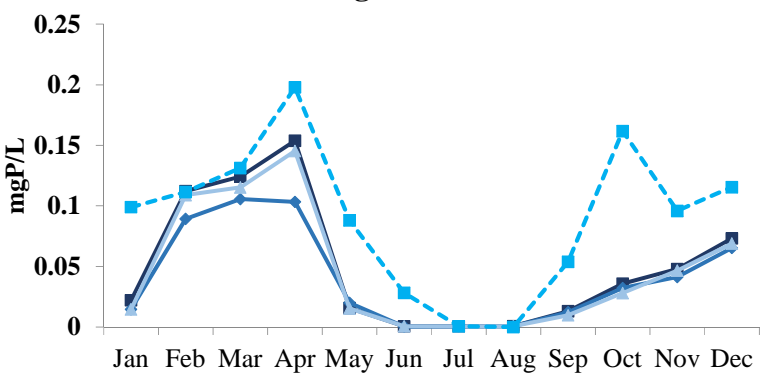

Month

$-\square-$ Baseline $\rightarrow$-Storyline $1 \multimap$ Storyline $2 \multimap$ Storyline 3

Figure 11. The monthly evolution of the $\mathrm{P}$ forms $\left(\mathrm{mg} \mathrm{P} \mathrm{L}^{-1}\right)$ for each storyline (timeline 2060 and GFDL climate model) and baseline: (a) Dissolved P; and (b) Organic P.

Results have also shown that the decrease of water in the basin had a significant influence on the quality of water in the river. Results for Total $\mathrm{N}$ and $\mathrm{P}$ concentrations (Figures 8 and 10) further suggest a significant deterioration of water quality in the Sorraia River, particularly with respect to the Total N.

\section{Conclusions and Future Research}

The modelling approach developed in this work highlighted possible cumulative impacts of future climatic changes in the Sorraia River basin by considering the expected changes in precipitation, 
temperature, and human activities. A significant decrease in precipitation is expected over the watershed for the near future (between $25 \%$ and $50 \%$ ). It is likely that this decrease will lead to an increase in irrigation and fertilization needs over this basin by $35 \%$. The water quantity is predicted to fall approximately by up to $75 \%$, while water quality shows an unbalanced deterioration, with nutrient concentrations predicted to increase up to $200 \%$ for P and up to $500 \%$ for N. Such a rise in nutrient concentration is observed to be a consequence of the increased use of fertilizers and decrease in water availability in rivers.

The results show how societal and especially climatic changes can affect river water quantity and quality in the study basin and can be considered as a starting point for defining appropriate management plans to counteract such negative impacts. The SWAT model can be further explored to test the effects of management practices and the degree of stress they introduce on the environment, thereby contributing to a cost-effective adaptive management practice. For instance, the use of winter crops with minimum water requirements, the implementation of no-till practices to improve soil structure and soil infiltration rates, the use of cover crops for reducing soil water evaporation or the establishment of more resilient cropping systems to cope with water scarcity may allow future impacts to be minimised at the basin level.

Author Contributions: C.A. set up the model, ran the simulations, and wrote the paper. T.B.R., P.S., P.B., R.N. and R.P.O. made revisions and improvements to the draft version.

Funding: This study was funded by the MARS Project (Managing aquatic ecosystems and water resources under multiple stress, http:/ / mars-project.eu) of the 7th Framework Programme of the European Commission (contract no. 603378). MARETEC acknowledges the national funds from the Foundation for Science and Technology (FCT) (Project UID/EEA/50009/2013). T. B. Ramos was supported by the FCT grant SFRH/BPD/110655/2015. Paulo Branco was financed by a post-doc grant from FCT (SFRH/BPD/94686/2013). Pedro Segurado is supported by a contract funded by the Fundação para a Ciência e Tecnologia (FCT) under the IF Researcher Programme (IF/01304/2015). CEF is a research unit funded by Fundação para a Ciência e a Tecnologia I.P. (FCT), Portugal (UID/AGR/00239/2013).

Conflicts of Interest: The authors declared no conflicts of interest.

\section{References}

1. Bürgi, M.; Hersperger, A.M.; Schneeberger, N. Driving forces of landscape change-Current and new directions. Landsc. Ecol. 2004, 19, 857-868. [CrossRef]

2. Hering, D.; Borja, A.; Cartensen, J.; Carvalho, L.; Elliot, M.; Feld, C.K.; Heiskanen, A.-S.; Johnson, R.K.; Moe, J.; Pont, D. The European Water Framework Directive at the age of 10: A critical review of the achievements with recommendations for the future. Sci. Total Environ. 2010, 408, 4007-4019. [CrossRef] [PubMed]

3. Hering, D.; Carvalho, L.; Argillier, C.; Beklioglu, M.; Borja, A.; Cardoso, A.C.; Duel, H.; Ferreira, T.; Globevnik, L.; Hanganu, J. Managing aquatic ecosystems and water resources under multiple stress-An introduction to the MARS project. Sci. Total Environ. 2015, 503, 10-21. [CrossRef] [PubMed]

4. Segurado, P.; Almeida, C.; Neves, R.; Ferreira, M.T.; Branco, P. Understanding multiple stressors in a Mediterranean basin: Combined effects of land use, water scarcity and nutrient enrichment. Sci. Total Environ. 2018, 624, 1221-1233. [CrossRef] [PubMed]

5. Hazell, P.; Wood, S. Drivers of change in global agriculture. Philos. Trans. R. Soc. B Biol. Sci. 2008, 363, 495-515. [CrossRef] [PubMed]

6. European Environment Agency, Water for Agriculture. Available online: https://www.eea.europa.eu/ articles/water-for-agriculture (accessed on 30 November 2017).

7. Alexandratos, N. World Agriculture: Towards 2010, a FAO Study; John Wiley and Sons Ltd.: Rome, Italy, 1995.

8. FAO. The State of the World's Land and Water Resources for Food and Agriculture (SOLAW)—Managing Systems at Risk; Food and Agriculture Organization of the United Nations: Rome, Italy, 2011.

9. Alexandratos, N.; Bruinsma, J. World Agriculture towards 2030/2050: The 2012 Revision. ESA Working Paper No. 12-03; Food and Agriculture Organization of the United Nations: Rome, Italy, 2012.

10. Sun, S.; Wang, Y.; Wang, F.; Liu, J.; Luan, X.; Li, X.; Zhou, T.; Wu, P. Alleviating Pressure on Water Resources: A new approach could be attempted. Sci. Rep. 2015, 5, 14006. [CrossRef] [PubMed] 
11. IPCC. Climate Change 2013: The Physical Science Basis. Contribution of Working Group I to the Fifth Assessment Report of the Intergovernmental Panel on Climate Change; Cambridge University Press: Cambridge, UK; New York, NY, USA, 2013.

12. Cordovil, C.; Cruz, S.; Brito, A.; Cameira, R.; Poulsen, J.; Thodsem, H.; Kronvang, B. A Simplified Nitrogen Assessment in Tagus River Basin: A Management Focused Review. Water 2018, 10, 406. [CrossRef]

13. Gasith, A.; Resh, V.H. Streams in Mediterranean climate regions: Abiotic influences and biotic responses to predictable seasonal events. Annu. Rev. Ecol. Syst. 1999, 30, 51-81. [CrossRef]

14. Riahi, K.; van Vuuren, D.P.; Kriegler, E.; Edmonds, J.; O’Neill, B.C. The Shared Socioeconomic Pathways and their energy, land use, and greenhouse gas emissions implications: An overview. Glob. Environ. Chang. 2017, 42, 153-168. [CrossRef]

15. O’Neill, B.C.; Kriegler, E.; Ebi, K.L.; Kemp-Benedict, E.; Riahi, K.; Rothman, D.S.; van Ruijven, B.J.; van Vuuren, D.P.; Birkmann, J.; Kok, K. The roads ahead: Narratives for shared socioeconomic pathways describing world futures in the 21st century. Glob. Environ. Chang. 2017, 42, 169-180.

16. Ning, L.; Riddle, E.E.; Bradley, R.S. Projected changes in climate extremes over the northeastern United States. J. Clim. 2015, 28, 3289-3310. [CrossRef]

17. Hosseinzadehtalaei, P.; Tabari, H.; Willems, P. Uncertainty assessment for climate change impact on intense precipitation: how many model runs do we need? Int. J. Climatol. 2017, 37, 1105-1117. [CrossRef]

18. Amatya, D.M.; Jha, M.K.; Williams, T.M.; Edwards, A.E.; Hitchcock, D.R. SWAT Model Prediction of Phosphorus Loading in a South Carolina Karst Watershed with a Downstream Embayment. J. Environ. Prot. 2013, 4, 75-90. [CrossRef]

19. Mateus, M.; Almeida, C.; Brito, D.; Neves, R. From Eutrophic to Mesotrophic: Modelling Watershed Management Scenarios to Change the Trophic Status of a Reservoir. Int. J. Environ. Res. Public Health 2014, 11, 3015-3031. [CrossRef] [PubMed]

20. Simionesei, L.; Ramos, T.B.; Oliveira, A.R.; Jongen, M.; Darouich, H.; Weber, K.; Proença, V.; Domingos, T.; Neves, R. Modeling soil water dynamics and pasture growth in the montado ecosystem using MOHID-Land. Water 2018, 10, 489. [CrossRef]

21. Brito, D.; Campuzano, F.J.; Sobrinho, J.; Fernandes, R.; Neves, R. Integrating operational watershed and coastal models for the Iberian Coast: Watershed model implementation-A first approach. Estuar. Coast. Shelf Sci. 2015, 167, 138-146. [CrossRef]

22. Brito, D.; Ramos, T.B.; Gonçalves, M.C.; Morais, M.; Neves, R. Integrated modelling for water quality management in a eutrophic reservoir in south-eastern Portugal. Environ. Earth Sci. 2018, 77, 40. [CrossRef]

23. APA. Plano de Gestão da Região Hidrográfica do Tejo. Relatório Técnico. Parte 2-Características Gerais da Região Hidrográfica; Ministério do Ambiente e do Ordenamento do Território: Lisboa, Portugal, 2012.

24. Neitsch, S.L.; Arnold, J.G.; Kiniry, J.R.; Williams, J.R. Soil and Water Assessment Tool; Theoretical Documentation, version 2009; Technical Report No. 406; Texas A\&M University System: College Station, TX, USA, 2011.

25. Serviço Nacional de Informação dos Recursos Hídricos. Available online: http://snirh.apambiente.pt/ (accessed on 30 November 2017).

26. Allen, R.G.; Pereira, L.S.; Raes, D.; Smith, M. Crop Evapotranspiration-Guidelines for Computing Crop Water Requirements - FAO Irrigation and Drainage Paper 56; Food and Agriculture Organization of the United Nations: Rome, Italy, 1998.

27. IUSS Working Group. World Reference Base for Soil Resources 2014. International Soil Classification System for Naming Soils and Creating Legends for Soil Maps; World Soil Resources Reports No. 106; FAO: Rome, Italy, 2014.

28. INE. Censos 2011-XV Recenseamento Geral da População e V Recenseamento Geral da Habitação; Instituto Nacional de Estatística: Lisboa, Portugal, 2011.

29. APA. Plano de Gestão de Região Hidrográfica. Parte 2-Caracterização e Diagnóstico. Região Hidrográfica do Tejo e Ribeiras do Oeste (RH5); Agência Portuguesa do Ambiente: Lisboa, Portugal, 2016.

30. Santhi, C.; Srinivasan, R.; Arnold, J.G.; Williams, J.R. A modeling approach to evaluate the impacts of water quality management plans implemented in a watershed in Texas. Environ. Model. Softw. 2006, 21, 1141-1157. [CrossRef]

31. Zhang, N.; He, H.M.; Zhang, S.F.; Jiang, X.H.; Zia, Z.Q.; Huang, F. Influence of Reservoir Operation in the Upper Reaches of the Yangtze River (China) on the Inflow and Outflow Regime of the TGR-based on the Improved SWAT Model. Water Resour. Manag. 2012, 26, 691-705. [CrossRef] 
32. Du, J.K.; Rui, H.Y.; Zuo, T.; Li, Q.; Zheng, D.; Chen, A.; Xu, Y.; Xu, C.-Y. Hydrological Simulation by SWAT Model with Fixed and Varied Parameterization Approaches Under Land Use Change. Water Resour. Manag. 2013, 27, 2823-2838. [CrossRef]

33. Koch, S.; Bauwe, A.; Lennartz, B. Application of the SWAT Model for a Tile-Drained Lowland Catchment in North-Eastern Germany on Subbasin Scale. Water Resour. Manag. 2013, 27, 791-805. [CrossRef]

34. USDA-SCS. National Engineering Handbook, Section 4; United States Department of Agriculture: Washington, DC, USA, 1972.

35. Cardoso, J.C. Os Solos de Portugal. Sua Classificação, Caracterização e Génese. 1-A Sul do Rio Tejo; Direcção-Geral dos Serviços Agrícolas: Lisboa, Portugal, 1965.

36. National Aeronautics and Space Administration. Available online: http://www.jpl.nasa.gov/srtm (accessed on 30 January 2017).

37. Nash, J.E.; Sutcliffe, J.V. River flow forecasting through conceptual models part I-A discussion of principles. J. Hydrol. 1970, 10, 282-290. [CrossRef]

38. Feld, C.K.; Segurado, P.; Gutiérrez-Cánovas, C. Analysing the impact of multiple stressors in aquatic biomonitoring data: A 'cookbook' with applications in R. Sci. Total Environ. 2016, 573, 1320-1339. [CrossRef] [PubMed]

39. O’Neill, B.C.; Kriegler, E.; Riahi, K.; Ebi, K.L.; Hallegatte, S.; Carter, T.R.; Mathur, R.; van Vuuren, D.P. A new scenario framework for climate change research: The concept of shared socioeconomic pathways. Clim. Chang. 2014, 122, 387-400. [CrossRef]

40. Moss, R.H.; Edmonds, J.A.; Hibbard, K.A.; Manning, M.R.; Rose, S.K.; van Vuuren, D.P.; Carter, T.R.; Emori, S.; Kainuma, M.; Kram, T.; et al. The next generation of scenarios for climate change research and assessment. Nature 2010, 463, 747-756. [CrossRef] [PubMed]

41. Warszawski, L.; Frieler, K.; Huber, V.; Piontek, F.; Serdeczny, O.; Schewe, J. The Inter-Sectoral Impact Model Intercomparison Project (ISI-MIP): Project framework. Proc. Natl. Acad. Sci. USA 2014, 111, 3228-3232. [CrossRef] [PubMed]

42. Wu, J.; Xu, Y.; Gao, X.-J. Projected changes in mean and extreme climates over Hindu Kush Himalayan region by 21 CMIP5 models. Adv. Clim. Chang. Res. 2017, 8, 176-184. [CrossRef]

43. Faneca Sanchez, M.; Duel, H.; Sampedro, A.A.; Rankinen, K.; Holmberg, M.; Prudhomme, C. Deliverable 2.1-Four Manuscripts on the Multiple Stressor Framework. Part 4: Report on the MARS Scenarios of Future Changes in Drivers and Pressures with Respect to Europe's Water Resources. Available online: http:/ / www.mars-project.eu/index.php/deliverables.html (accessed on 30 November 2017).

44. Birk, S.; Strackbein, J.; Faneca Sanchez, M.; Schmidt-Kloiber, A.; St. John, R. MARS Deliverable 8.4: Fact Sheets Including a Set of Illustrations. Available online: http:/ / www.mars-project.eu/files/download/ deliverables/MARS_D8.4_fact_sheets.pdf (accessed on 30 November 2017).

45. Dunne, J.P.; John, J.G.; Adcroft, A.J.; Griffies, S.M.; Hallberg, R.W.; Shevliakova, E.; Stouffer, R.J.; Cooke, W.; Dunne, K.A.; Harrison, M.J.; et al. GFDL's ESM2 Global Coupled Climate-Carbon Earth System Models. Part I: Physical Formulation and Baseline Simulation Characteristics. J. Clim. 2012, 25, 6646-6665.

46. Dunne, J.P.; John, J.G.; Shevliakova, E.; Stouffer, R.J.; Krasting, J.P.; Malyshev, S.L.; Milly, P.C.; Sentman, L.T.; Adcroft, A.J.; Cooke, W.; et al. GFDL's ESM2 Global Coupled Climate-Carbon Earth System Models. Part II: Carbon System Formulation and Baseline Simulation Characteristics. J. Clim. 2013, 26, 2247-2267. [CrossRef]

47. Dufresne, J.L.; Foujols, M.A.; Denvil, S.; Caubel, A.; Marti, O.; Aumont, O.; Balkanski, Y.; Bekki, S.; Bellenger, H.; Benshila, R. Climate change projections using the IPSL-CM5 Earth System Model: From CMIP3 to CMIP5. Clim. Dyn. 2013, 40, 2123-2165. [CrossRef]

48. Hempel, S.; Frieler, K.; Warszawski, L.; Schewe, J.; Piontek, F. A trend-preserving bias correction-the ISI-MIP approach. Earth Syst. Dyn. 2013, 4, 219-236. [CrossRef]

49. Shrestha, M. Data Analysis Relied on Linear Scaling Bias Correction (V.1.0). 2015. Available online: https:// www.researchgate.net/publication/289290337_Linear_Scaling_bias_correction_V10_Microsoft_Excel_file (accessed on 30 November 2017).

50. Shrestha, M.; Acharya, S.C.; Shrestha, P.K. Bias correction of climate models for hydrological modelling-Are simple methods still useful? Meteorol. Appl. 2017, 24, 531-539. [CrossRef]

51. Giorgi, F.; Lionello, P. Climate change projections for the Mediterranean region. Glob. Planet. Chang. 2008, 63, 90-104. [CrossRef] 
52. Erol, A.; Randhir, T.O. Climatic change impacts on the ecohydrology of Mediterranean watersheds. Clim. Chang. 2012, 114, 319-341. [CrossRef]

53. Bucak, T.; Trolle, D.; Tavşanoğlu, Ü.; Çakıroğlu, A.; Özena, A.; Jeppesen, E.; Beklioğlu, M. Modeling the effects of climatic and land use changes on phytoplankton and water quality of the largest Turkish freshwater lake: Lake Beyşehir. Sci. Total Environ. 2018, 621, 802-816. [CrossRef] [PubMed]

54. Pascual, D.; Pla, E.; Lopez-Bustins, J.A.; Retana, J.; Terradas, J. Impacts of climate change on water resources in the Mediterranean Basin: A case study in Catalonia, Spain. Hydrol. Sci. J. 2015, 60, 2132-2147. [CrossRef]

55. Ramos, T.B.; Simionesei, L.; Jauch, E.; Almeida, C.; Neves, R. Modelling soil water and maize growth dynamics influenced by shallow groundwater conditions in the Sorraia Valley region, Portugal. Agric. Water Manag. 2017, 185, 27-42. [CrossRef]

56. Cameira, M.R.; Fernando, R.M.; Ahuja, L.R.; Ma, L. Using RZWQM to simulate the fate of nitrogen in field soil-crop environment in the Mediterranean region. Agric. Water Manag. 2007, 90, 121-136. [CrossRef]

57. Cameron, K.C.; Di, H.J.; Moir, J.L. Nitrogen losses from the soil/plant system: A review. Ann. Appl. Biol. 2013, 162, 145-173. [CrossRef]

58. Lamb, J.A.; Fernandez, F.G.; Kaiser, D.E. Understanding Nitrogen in Soils. Available online: http:// www.extension.umn.edu/agriculture/nutrient-management/nitrogen/understanding-nitrogen-in-soils/ (accessed on 30 November 2017).

59. Ramos, T.B.; Šimůnek, J.; Gonçalves, M.C.; Martins, J.C.; Prazeres, A.; Pereira, L.S. Two-dimensional modeling of water and nitrogen fate from sweet sorghum irrigated with fresh and blended saline waters. Agric. Water Manag. 2012, 111, 87-104. [CrossRef]

60. Serpa, D.; Nunes, J.P.; Keizer, J.J.; Abrantes, N. Impacts of climate and land use changes on the water quality of a small Mediterranean catchment with intense viticulture. Environ. Pollut. 2017, 224, 454-465. [CrossRef] [PubMed]

(C) 2018 by the authors. Licensee MDPI, Basel, Switzerland. This article is an open access article distributed under the terms and conditions of the Creative Commons Attribution (CC BY) license (http://creativecommons.org/licenses/by/4.0/). 